\title{
POROSITY, PERMEABILITY AND MiCROSTRUCTURE OF FOAMED CONCRETE THROUGH SEM IMAGES
}

\author{
P. Shawnim* and F. Mohammad \\ School of Architecture, Design and the Built Environment, Nottingham Trent University, Burton Street, Nottingham, NG1 \\ 4BU, UK. \\ Date received: 12/10/2018, Date accepted: 14/02/2019 \\ *Corresponding author's email: paybar.shawnim2014@my.ntu.ac.uk and fouad.mohammad@ntu.ac.uk \\ https://doi.org/10.33736/jcest.1434.2019
}

\begin{abstract}
This paper examined the Foamed Concrete (FC) for permeability of total and capillary water absorption, at 28 days of air sealed curing. The microstructure of 15 selected FC specimens was investigated to determine permeability in relation to porosity and density using Scanning Electron Microscopy (SEM) images. The FC specimens of the densities (1100, 1600 , and 1800) $\mathrm{kg} / \mathrm{m} 3$ were made using fine sand and brick aggregates with toner and MK inclusion as additives. The microstructural investigation of the FC revealed, porosity measure as a percentage ratio of the area under investigation to be in the range of (39.65 to 77.7) \%. The pore size is in the range of (0.01 to 70) $\mu \mathrm{m}$, depending on the type of additive, for the mixes containing toner and MK, it is in a fine range of $(0.01$ to 10.0$) \mu \mathrm{m}$. For the FC specimens, the finer the pore size, the less permeable and the stronger it is. Permeability is porosity and strength dependent, whereby high porosity leads to high permeability and low compressive strength for FC mixes made with sand or brick only with no additive inclusion. Meanwhile, the FC mixes made with the inclusion of additives, such as the toner and MK20 mixes, showed an evenly spread net of independent air voids with a regular shape within their matrix, which is beneficial in decreasing permeability. Therefore, besides the porosity and strength, the fineness of the pore matrix and the shape factor of the pores are two other key factors in controlling permeability. Toner and MK20 inclusion can enhance the capillary water absorption to reach almost water tight. Besides, MK30 and MK50 inclusion displayed adverse effect on permeability. Depending on the type of filler, the additive, and the percentage ratio of the porosity of the FC matrix at (1600 and 1800) kg/m 3 densities, it is possible to produce FC with compressive strength between (55.1 and 30) N/mm².
\end{abstract}

Copyright $(2) 2019$ UNIMAS Publisher. This is an open access article distributed under the Creative Commons Attribution-NonCommercial-ShareAlike 4.0 International License which permits unrestricted use, distribution, and reproduction in any medium, provided the original work is properly cited.

Keywords: Foamed concrete, microstructure, permeability, porosity, SEM

\subsection{INTRODUCTION}

Foamed concrete is a lightweight material with densities that vary between $(400-1800) \mathrm{kg} / \mathrm{m}^{3}$ [1], known for good workability, self-flowing, and self-compacting, used for gap filling and the construction of nil structural elements. Foamed concrete is made up of Ordinary Portland cement (OPC), sand and water with no gravels, having a net of well-spread air voids or pore structure, created by the introduction of air by mechanical means of foaming. The foam can be generated from natural surfactants or synthetic materials, which can be added to the concrete mix either as pre-foamed or as mixed foaming [2]. The production of a stable FC mix depends on many factors, namely selection of the foaming agent, method of the foam preparation, and the addition of the foam for a uniform air-voids distribution. The materials section and the mixture design strategies, the production of foam concrete, and the performance with respect to fresh and hardened states are of a greater significance [3]. Ramamurthy et al. [3] found that concrete with uniform distribution of air-void sizes, circular air-voids, and optimal spacing between voids can produce FC with good mechanical properties. The water absorption of FC is decreased with density, while it is increased for the cement-sand mixes, therefore, water absorption of FC should be expressed in $\mathrm{kg} / \mathrm{m}^{3}$ rather than as a percentage by weight because of its reduced density.

Ramamurthy et al. [3] further stated that the durability studies showed that the cell-like structure and possible porosity do not make it less resistant to penetration of aggressive ions than the densely compacted normal weight concrete. This is because; the ratio of connected pores to total pores that determines the durability, is lower in FC. Hence, it has good resistance to freeze and thaw, fire, thermal conductivity, and possesses lower sorptivity. Experimental models have been proposed to relate porosity and strength 
of porous materials, some models relating strength to porosity have been presented for aerated concrete [4], and for FC [5]. Kumara and Bhattacharjeeb [6] studied the pore system and suggested a new model that considered porosity, pore size distribution, cement content of concrete, aggregate type, exposure condition, and age of concrete. They also found that the existing models related to strength with pore size characteristics of cement-based material were inadequate for proper explanation. Air-void distribution is more uniform at a low dosage of foam volume than at a high foam volume content, this uniformity is true in FC containing fly ash mixes in comparison to concrete of sand mixes only [7].

Xingang et al. [8] showed that the pore diameters of the light weight and high strength FC are mainly in the range of (100-200) $\mu \mathrm{m}$. Even distribution of fine and close pores resulted in high strength and low permeability, while uneven distribution of large size pores and open pores lead to low strength and high permeability. Xingang et al. [8] further stated that scanning electron microscopy (SEM) is appropriate for the pore structure and microstructural analyses of FC. Visagie and Kearsley [9] found that at higher densities, the air void distribution does not seem to have an influence on the compressive strength, which may be related to a more uniform distribution of air voids at higher densities. Luping [10] stated that the bigger pores have effects on the strength of concrete, rather than the smaller pores, materials with the same matrix and porosity, the strength is lower for that which contains more of the large size pores. Both, the critical pore diameter and the pore range with diameter $>200 \mathrm{~nm}$ decreased with increase in the density. There is a strongly positive relationship between them and the permeability of FC, and that many of the artificial pores due to the added foam did not take part in water absorption, indicating that many of them are not interconnected [11]. As for the concept of shape factor, Lange et al. [12] and Zhang et al. [13] stated that air-void shape has no influence on the properties of FC.

\subsection{METAKAOLIN (MK) AS AN ADDITIVE IN CONCRETE:}

Metakaolin (MK) is considered as an ultrafine pozzolanic material with particle size of less than $2.0 \mu \mathrm{m}$. It is produced by calcining purified kaolinite clay at a temperature ranging from 700 to $900 \mathrm{C}^{0}$, to drive off water from the kaolin $\left(\mathrm{Al}_{2} \mathrm{O}_{3} \cdot 2 \mathrm{SiO}_{2} \cdot 2 \mathrm{H}_{2} \mathrm{O}\right)$, and the structure of the material collapses resulting in an amorphous aluminosilicate $\left(\mathrm{Al}_{2} \mathrm{O}_{3} \cdot 2 \mathrm{SiO}_{2}\right), \mathrm{MK}$ [15], [16] and [17]. Table (1) shows the chemical composition of Portland Cement (PC) and MK.

Table 1. Chemical composition (\%) of Portland Cement (PC) and Metakaolin (MK)

\begin{tabular}{|c|c|c|}
\hline Composition & OPC (\%) & MK (\%) \\
\hline $\mathrm{SiO}_{2}$ & 20.1 & 52 \\
\hline $\mathrm{Fe}_{2} \mathrm{O}_{3}$ & 2.3 & 4.6 \\
\hline $\mathrm{Al}_{2} \mathrm{O}_{3}$ & 4.4 & 41 \\
\hline $\mathrm{CaO}$ & 63.4 & 0.1 \\
\hline $\mathrm{MgO}$ & 2.3 & 0.2 \\
\hline $\mathrm{SO}_{3}$ & 3.2 & - \\
\hline $\mathrm{Na}_{2} \mathrm{O}$ & 0.14 & 0.1 \\
\hline $\mathrm{K}_{2} \mathrm{O}$ & 0.67 & 0.6 \\
\hline $\mathrm{TiO}_{2}$ & - & 0.81 \\
\hline LOI & 2.81 & 0.6 \\
\hline
\end{tabular}

Metakaolin utilization, is considered as environmentally friendly, and for that, it helps in the reduction of Portland cement (PC) consumption, which in turn, helps in the reduction of $\mathrm{CO}_{2}$ emission into the surroundings. Cherem et al. [18] found that the inclusion of MK remarkably reduced the drying shrinkage. Metakaolin exhibits pozzolanic activity through which it can accelerate the early stages of hydration of cement pastes and mortars. MK inclusion leads to durability enhancement through pore refinement and reduction in calcium hydroxide of the cement paste matrix [19]. Improvement in workability, durability to thermal cracking, durability to chemical attacks, and production of high-performance concrete suggest 
high strength and low shrinkage. Gruber et al. [20] reported that (8\%-12\%) levels of MK substitution can increase the resistance to chloride ion penetration, i.e. to improve permeability. Metakaolin in concrete can increase compressive strength and reduce permeability with good workability [21]. According to some researches in this field, MK is said to have beneficial effects as to the refinement of the pore structure of the concrete [16], as it can reduce porosity and decrease permeability [22].

\subsection{CLAY BRICK AGGREGATES (COARSE AND FINE) AS ADDITIVE IN CONCRETE}

Many researchers have used clay brick as coarse aggregates, and some have applied it as coarse and fine. Meanwhile, Bektas and Wang K., 2012 [23], Moriconi et al. 2003 [24] and Turanli et al. 2003 [25] used ground clay brick powder (GBP) as partial replacement of cement in concrete and classify GBP as pozzolanic materials. For chemical composition of the cementitious materials of clay brick, see Table (2).

Table 2. Chemical composition (\%) of the cementitious materials of clay brick

\begin{tabular}{cc}
\hline Composition & Ground clay brick powder (GBP) $(\%)$ \\
\hline $\mathrm{CaO}$ & 0.81 \\
$\mathrm{SiO}_{2}$ & 69.9 \\
$\mathrm{Al}_{2} \mathrm{O}_{3}$ & 15.38 \\
$\mathrm{Fe}_{2} \mathrm{O}_{3}$ & 6.78 \\
$\mathrm{MgO}$ & 1.58 \\
$\mathrm{SO}_{3}$ & 0.04 \\
$\mathrm{~K}_{2} \mathrm{O}$ & 2.78 \\
$\mathrm{Na}_{2} \mathrm{O}$ & 1.02 \\
Loss on ignition & 0.16 \\
\hline
\end{tabular}

Aliabdo et al. [26] noticed improvement in compressive strength at $25 \%$ and $50 \%$ replacement, for which continued by increasing GBP aggregate content, they also found that it was possible to achieve a concrete of high strength using clay brick as coarse aggregates. Debieb and Kenai [27] found that porosity is becoming significant when strength of concrete decreases.

Clay brick aggregates present a relatively lower density and higher water absorption compared to natural aggregates. Debieb and Kenai [27] reported a decrease in compressive strength of about 30, 35 and 40\% at 28 days of age when coarse, fine, or both fine and coarse aggregates were substituted, reduction of $30 \%, 40 \%$ and $50 \%$ were observed for concrete made with coarse, fine and both coarse and fine ground bricks, while shrinkage and water permeability increased using ground bricks. Therefore, Debieb and Kenai [27] and Ibrahim et al. [28] restricted the limit to $25 \%$ and 50\% for coarse and fine aggregates as optimum percentages to produce a quality concrete with characteristics similar to those of natural aggregates concrete. Debieb and Kenai [27] and Ibrahim et al. [28] also found compressive strength enhancement at 50\% replacement of GBP, was increased, as well as porosity, when GBP content was increased, which could be attributed to its pozzolanic characteristics, resulted in a porous structure. Aliabdo et al. [26] recommended saturation of the GBP for FC mixes, to enhance workability and volume stability, which is also supported by Cachim [29] and Ibrahim et al. [28], stating that incorporation of clay brick into the concrete will increase workability.

\subsection{TONER}

This is a newly found material to be used in this field of FC, therefore, there is no published data available for its usage in this field. This material comes in the form of a powder from the unused or waste cartridges of printers, which is going to be used as an additive in the experimental mixes, at $1 \%$ and $5 \%$ of the binding cementitious material (cement). This material had been chosen for this research because it is 
widely available as a waste material for recycling and to help in a cleaner environment by reducing buried waste and $\mathrm{CO}^{2}$ emission around the world. Table 3 shows chemical composition for toner. Besides, toner includes the following additives for flow and lubrication purposes: fumed silica and metal stearates.

Table 3. Chemical composition of toner [30]

\begin{tabular}{lc}
\hline Toner Type & Composition \\
\hline Plastic (Styrene acrylate copolymer, polyester resin) & $65-85 \%$ or $55-65 \%$ \\
iron oxide & $6-12 \%$ or $30-40 \%$ \\
Wax, ground sand & $1-5 \%$ \\
Amorphous silica & $1-3 \%$ \\
Carbon black & $1-10 \%$ \\
\hline
\end{tabular}

This paper investigated porosity and permeability in relation to density and compressive strength. For this, different experimental FC mixes were used, which contained newly introduced additives, such as toner and MK, in addition to the sand and brick aggregates, which were used as fillers. As for the microstructural analysis, the SEM was performed on the images to investigate the pore matrix, i.e. pore size, pore size distribution, and their shapes, to analyse permeability in this respect, in relation to density and compressive strength.

\subsection{EXPERIMENTAL WORK}

The experiment was carried out in the laboratory in accordance to the relevant British Standards (BS) for each part of the process. Sets of $(100 \times 100 \times 100) \mathrm{mm}$ disposable polystyrene cube moulds were used to cast all concrete samples containing the foam, enabling air sealed curing process of the desired curing period of (28) days before testing (Figure 1). Twenty-two batches of different concrete mixes were made with OPC, fine sand $(0-0.5) \mathrm{mm}$, and brick aggregates $(0-0.5$ and 10.0$) \mathrm{mm}$ as a filler, and $\mathrm{MK}$ and toner added at different doses as additives with a w/c ratio of 0.5 . Addition of toner at $1 \%$ or $5 \%$ by weight of the cement had no effect on water demands for the mixes involved. The foam was added at different percentages to the mixes to produce the desired densities. The foaming agent used in this project was a protein-based foaming agent, wherein dry pre-foaming method was used to generate the foam. The cement content of the FC for all the batches had been kept constant at $(500-600) \mathrm{kg} / \mathrm{m}^{3}$ which is comparable with other studies carried out in this field [14]. Compressive strength and permeability through capillary water absorption and total water absorption, were measured at (28) days.

As for the microstructural investigation of the FC matrix, samples from 15 selected specimens were studied via secondary electron (SE) and backscattered electron (BS) images captured using SEM in the form of 2D-images, and the images were analysed using Image J software. Images were taken at 500X, 2000X, and 10000X magnification, while the 2000X magnification was analysed in this study for clarity to meet the purpose. For this technique, samples of about $(10 \times 10) \mathrm{mm}$ size with a thickness of about 6 $\mathrm{mm}$ were cut from the cured specimens, using microtome (a diamond cutter). To produce the best electron images and to eliminate distortion of SE and BS images due to negative charges, the samples were coated and polished with slow set epoxy resin, and with a thin film of gold (conductive material) prior to SEM analysis. This is compatible to the techniques used in this field [31]. Porosity as a percentage ratio (\%), pore sizes and pore size distribution of the selected 15 specimens, namely (S3, S4, S5, S7, S8, S10, S11, S12, S13, S14, S15, S16, S18, S19 and S20) were found in the area under investigation (see Table (4)). 
Table 4 Compressive strength in $\left(\mathrm{N} / \mathrm{mm}^{2}\right)$ for different curing methods and tests of the specimens, S1 to S22, with porosity ratio $(\%)$

\begin{tabular}{|c|c|c|c|c|c|c|}
\hline Label & Type of concrete cast: & $\begin{array}{c}\text { Dry } \\
\text { Density } \\
\left(\mathrm{Kg} / \mathrm{m}^{3}\right)\end{array}$ & $\begin{array}{l}\text { Capillary water } \\
\text { absorption } 5 \text { bar } \\
\text { (mm) }\end{array}$ & $\begin{array}{l}\text { Total water } \\
\text { absorption } \\
\left(\mathrm{Kg} / \mathrm{m}^{3}\right)\end{array}$ & $\begin{array}{l}\text { Compressive } \\
\text { strength } 28 \\
\text { days } \\
\left(\mathrm{N} / \mathrm{mm}^{2}\right)\end{array}$ & $\begin{array}{l}\text { Porosity } \\
\text { (\%) }\end{array}$ \\
\hline S1 & Sand & 2000 & 26 & 187.7 & 53.3 & \\
\hline $\mathrm{S} 2$ & Sand & 1800 & 67 & 210 & 31 & \\
\hline $\mathrm{S} 3$ & Sand & 1100 & 100 & 288.7 & 7.4 & 60 \\
\hline S4 & Sand and MK20 & 1800 & 20 & 122 & 49.7 & 39.8 \\
\hline S5 & Sand and MK20 & 1600 & 34 & 170.7 & 47 & 54 \\
\hline S6 & Sand and MK20 & 1100 & 57 & 221 & 10.2 & \\
\hline S7 & Sand and MK30 & 1600 & 81 & 205 & 38 & 65.1 \\
\hline S8 & Sand and MK30 & 1100 & 74 & 288 & 31 & 70 \\
\hline S9 & Sand and MK50 & 1600 & 90 & 349.7 & 30 & \\
\hline S10 & Sand and MK50 & 1100 & 100 & 444 & 26.1 & 77.7 \\
\hline S11 & Brick aggregates & 1800 & 70 & 243 & 47.3 & 46.4 \\
\hline $\mathrm{S} 12$ & Brick aggregates & 1600 & 86 & 249 & 40.6 & 53.5 \\
\hline S13 & Brick aggregates & 1100 & 100 & 270 & 14.1 & 66 \\
\hline S14 & Brick and MK20 & 1600 & & 130.4 & 46 & 44.5 \\
\hline S15 & Brick and MK20 & 1100 & 55 & 160.5 & 25.6 & 51.6 \\
\hline S16 & Sand and Toner & 1800 & 2 & 133.3 & 48.1 & 39.6 \\
\hline S17 & Sand and Toner (5\%) & 1800 & 1 & 120 & 55.1 & \\
\hline S18 & Sand and Toner & 1100 & 60 & 172 & 15 & 57.7 \\
\hline S19 & Brick and Toner & 1600 & 5 & 170.1 & 43.8 & 46.6 \\
\hline S20 & Brick and Toner & 1100 & 35 & 188 & 33.4 & 57 \\
\hline S21 & Brick and Toner (5\%) & 1600 & 3 & 115.2 & 50.5 & \\
\hline S22 & Brick and Toner $(5 \%)$ & 1100 & 16 & 165.4 & 38.2 & \\
\hline
\end{tabular}

\subsection{CAPILLARY WATER ABSORPTION}

Capillary water absorption test was carried out under 5 bar pressure in accordance to BS EN 123908:2009 [32]. Three oven-dried specimens were placed under the 5 bar permeability test apparatus for 72 hours, after which they were taken out and split open to mark and measure water penetration from bottom up. The results reported as an average of the three specimens, expressed in millimetres $(\mathrm{mm})$ (see Figures 2 and 3$)$.

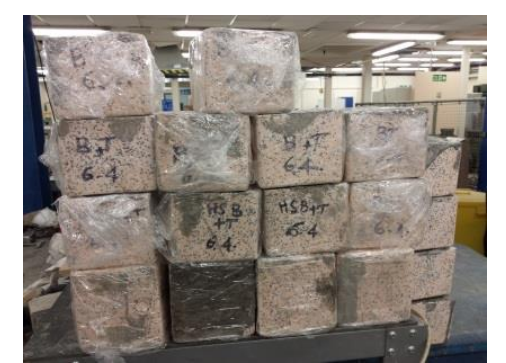

Figure 1 Sealed cubes in cling film for curing

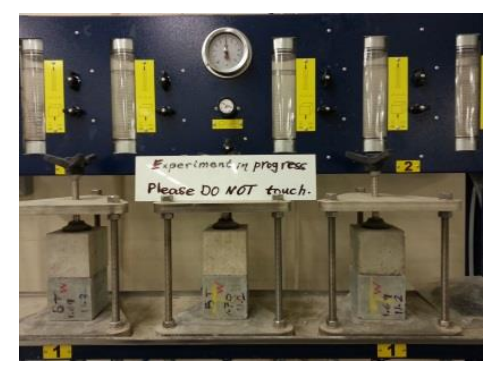

Figure 2 Permeability apparatus

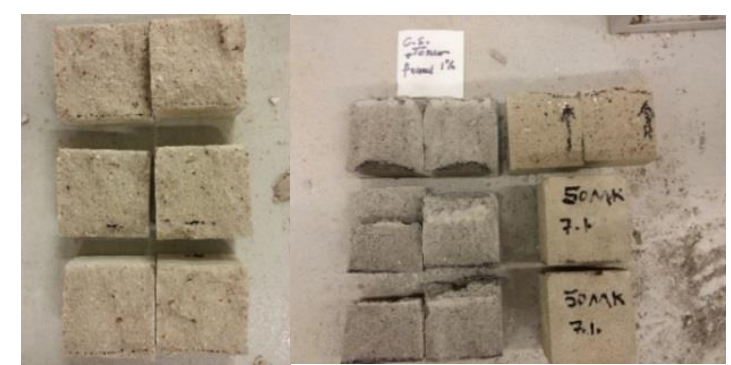

Figure 3 Specimens split-open and marked

\subsection{TOTAL WATER ABSORPTION}

Total water absorption test was carried out in accordance with BS 1881-122:2011 [33]. Three-oven dried were totally immersed in water for at least 72 hours, after which they were taken out to measure the weight 
of the absorbed water. The absorbed water was determined from the difference in weight between fully water saturated and dried state of specimens. The results are expressed in $\left(\mathrm{kg} / \mathrm{m}^{3}\right)$ of the dried weight.

\subsection{COMPRESSIVE STRENGTH AT 28 DAYS}

The test was carried out with a digital log keeping and digitally controlled automatic loading machine in accordance with BS EN 12390-3:2009 [34]. The oven-dried cubes were placed centrally under the loading plates. The results quoted in each case are the average of six specimens.

\subsection{DATA ANALYSIS AND FINDINGS}

Looking at Figure (4) for total water absorption, specimen S21 of $1600 \mathrm{~kg} / \mathrm{m}^{3}$ density displayed the lowest total water absorption of $115.2 \mathrm{~kg} / \mathrm{m}^{3}$, followed by S17, S4, S14, S16, S15, S22, S19, S5 and S18 with $(120,122,130.4,133.3,160.5,165.4,170.1,170.7,172) \mathrm{kg} / \mathrm{m}^{3}$ are way below $187.7 \mathrm{~kg} / \mathrm{m}^{3}$ density of $\mathrm{S} 1$ (the normal concrete) of $2000 \mathrm{~kg} / \mathrm{m}^{3}$ (with no foam) taken as control specimen for comparison, and S20 of $188 \mathrm{~kg} / \mathrm{m}^{3}$ at this density. Apart of S4, S16, and S17, which are of $1800 \mathrm{~kg} / \mathrm{m}^{3}$ densities, all of these specimens mentioned have either toner or MK20 inclusion within their matrix and are of the densities (1100 and 1600) kg/m 3 . S9 and S10 of (349.7 and 444) $\mathrm{kg} / \mathrm{m}^{3}$ densities, recorded the worst scenario in respect of total water absorption. Inclusion of toner or MK20 for sand or brick as a filler showed improvement in respect of total water absorption for (1100 and 1600) $\mathrm{kg} / \mathrm{m}^{3}$ densities.

The total water absorption for specimens S21 and S22 brick containing (1600 and 1100$) \mathrm{kg} / \mathrm{m}^{3}$ toner at 5\% closely matched S14 and S15 brick containing the same densities, respectively with MK20 inclusion. This means; toner has the same effect as MK20, which goes back to the lubricating metal stearates from the toner to form a fine coating film around the binding particles and the air voids, resulting in a stronger and closely packed water resistant cellular concrete matrix for both capillary water absorption and total water absorption improvement. S2 and S3 of (1800 and 1100) $\mathrm{kg} / \mathrm{m}^{3}$ densities for sand as filler alone, and $\mathrm{S} 11$ to $\mathrm{S} 13$ of $(1800,1600$ and 1100$) \mathrm{kg} / \mathrm{m}^{3}$ densities, respectively, for brick as filler alone, showed high total water absorption compared to S1 (control specimen).

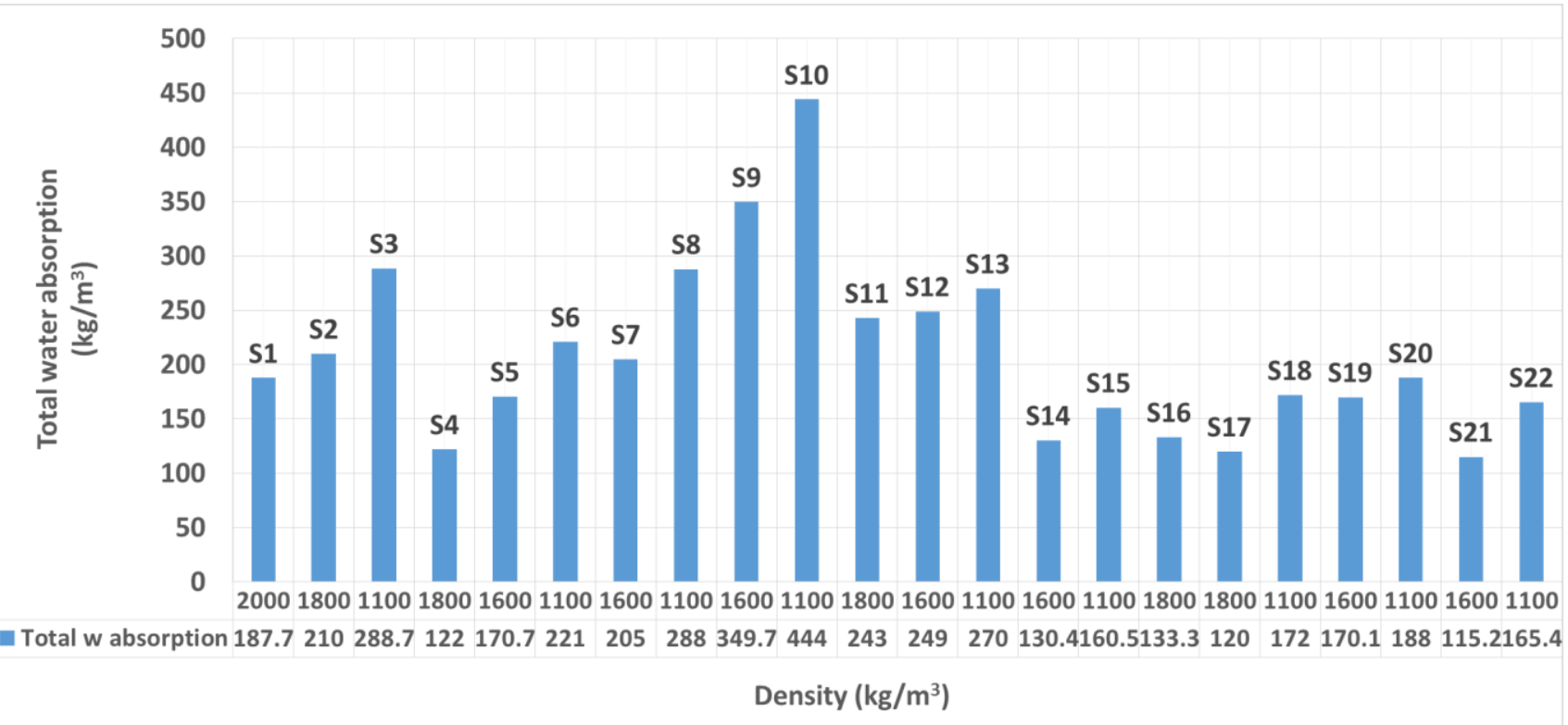

Figure 4 Total water absorption $\left(\mathrm{kg} / \mathrm{m}^{3}\right)$ of dry weight versus density for different mixes containing sand and brick as filler, with the inclusion of toner and MK as additives for specimens with 28 days of sealed curing.

Sand specimens S7 and S8 containing MK30, S9 and S10 contained MK50 of (1600 and 1100) kg/m $\mathrm{m}^{3}$ densities respectively, showed the same high total water absorption. All toner-included specimens (S16 to S22) for all the three densities, namely $\left(1800,1600\right.$ and 1100) $\mathrm{kg} / \mathrm{m}^{3}$, displayed improvement in respect 
of total water absorption, regardless of having sand or brick as filler within their matrix. Sand specimens of low densities of $1100 \mathrm{~kg} / \mathrm{m}^{3}$ namely S6, S8, and S10 cannot be improved with MK inclusion to reach that of the control specimen S1, but it can be with toner for total water absorption, even when strength is as low as $15 \mathrm{~N} / \mathrm{mm}^{2}, \mathrm{~S} 18$. Besides, MK20 inclusion can improve the total water absorption for sand or brick as a filler at $1600 \mathrm{~kg} / \mathrm{m}^{3}$ densities. Brick particles are porous to a certain degree, which has the ability to absorb and keep more water for better curing later, and has pozzolanic reactivity, adding to the strength. When the brick particles react with MK20 and toner, it will refine the pores, improving the pore size and pore size distribution within the FC matrix. This minimises both porosity and permeability.

For capillary water absorption under 5 bar, Figure (5) shows that S17, S16, S21, and S19 of (1800, 1800, 1600 and 1600) $\mathrm{kg} / \mathrm{m}^{3}$ densities respectively, toner inclusion for sand or brick as filler with capillary water absorption of ( 1 to 5 ) $\mathrm{mm}$, only getting dampness to the outer layer of the specimen, close to water tight improvement. Capillary water absorption showed improvement through specimens, S14 and S5 of 1600 $\mathrm{kg} / \mathrm{m}^{3}$ densities, with (15 and 34) mm, S4 of $1800 \mathrm{~kg} / \mathrm{m}^{3}$ densities with $20 \mathrm{~mm}$, and S20, S15, S18, and $\mathrm{S} 6$ of $1100 \mathrm{~kg} / \mathrm{m}^{3}$ densities with $(35,55,60$ and 57) $\mathrm{mm}$ respectively. These specimens, which showed improvement, were made with toner or MK20 inclusion, compared to the sand made specimens of S2 or $\mathrm{S} 3$ of (1800 and 1100) kg/m³ density, having (67 and 100) $\mathrm{mm}$ of capillary water absorption respectively. There is no standard for an acceptable level of capillary water absorption, while the minimum water penetration should be taken as an acceptable level, which depended on the application of the FC used for.

Regardless of the type of the filler used, S4, S14, S16, S17, S19 and S21 of (20, 15, 2, 1, 5 and 3) mm having either MK20 or toner inclusion within their matrix, and are of $1800 \mathrm{~kg} / \mathrm{m}^{3}$ density or below, showed better resistance against water absorption compared to $\mathrm{S} 1$ of $2000 \mathrm{~kg} / \mathrm{m}^{3}$ density with $26 \mathrm{~mm}$, taken as control specimen. Sand or brick made alone S3, S13 and S12 of (1100, 1100 and 1600) kg/m $\mathrm{m}^{3}$ densities respectively, showed the worst scenario in respect of the capillary water absorption. Besides, S2 and $\mathrm{S} 11$ of $1800 \mathrm{~kg} / \mathrm{m}^{3}$ densities and specimens made with the inclusion of $\mathrm{MK}$ at $30 \%$ or $50 \%$, namely $\mathrm{S} 7$ and $\mathrm{S} 9$ of $1600 \mathrm{~kg} / \mathrm{m}^{3}$ densities, $\mathrm{S} 8$ and $\mathrm{S} 10$ of $1100 \mathrm{~kg} / \mathrm{m}^{3}$ densities, showed poor resistance to capillary water absorption. Meanwhile, S21, S19, S14, and S5 of $1600 \mathrm{~kg} / \mathrm{m}^{3}$ densities with $(3,5,15,34)$ $\mathrm{mm}$, toner or MK20 inclusion have compressive strength of $\left(50.5,43.8,46\right.$ and 47) $\mathrm{N} / \mathrm{mm}^{2}$ respectively, displayed significant improvement in respect of permeability and compressive strength alike.

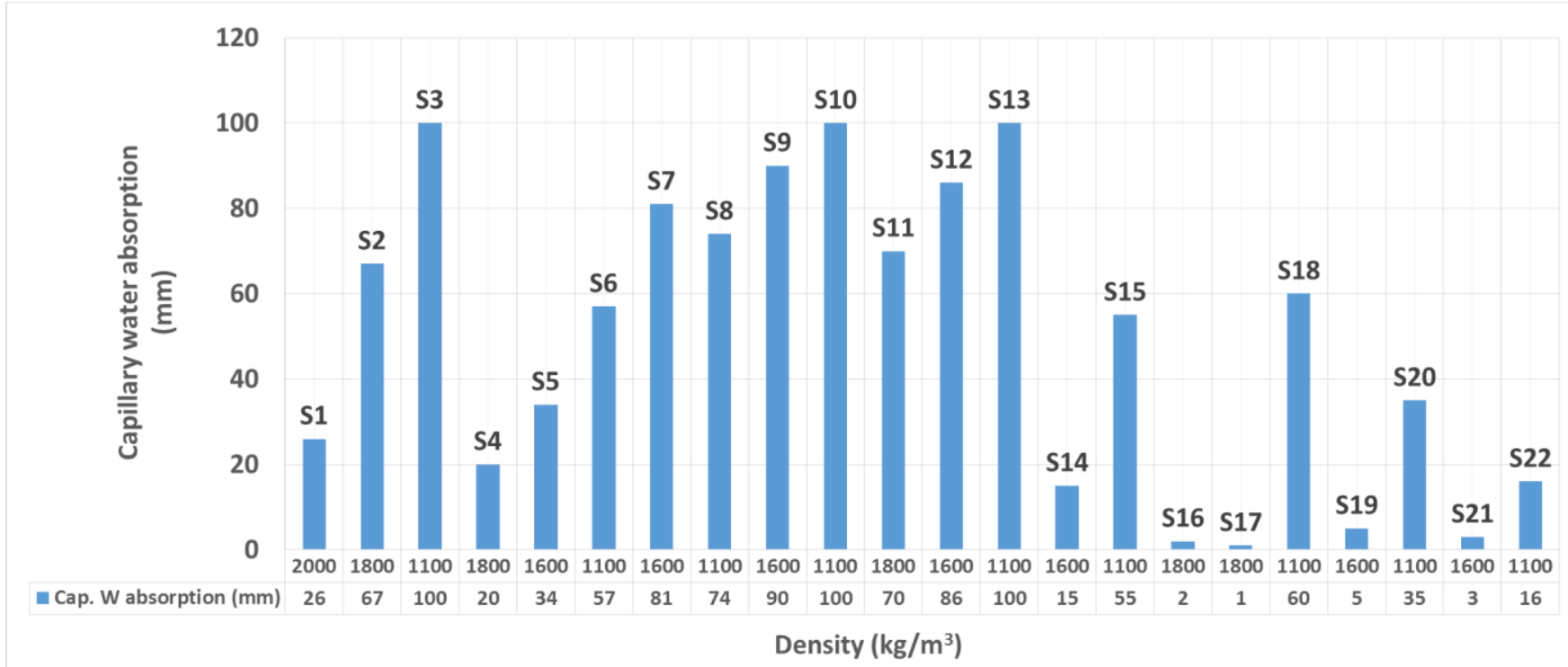

Figure 5 Capillary water absorption $(\mathrm{mm})$ versus density for different mixes containing sand and brick as fillers, with the inclusion of toner and MK as additives for specimens with 28 days of air-sealed curing

For porosity through SEM image analysis (see Figures (6, 7 and 8)), S16, S4, S14, and S19 with close range porosities of $(39.6,39.8,44.5$, and 46.6$) \%$ respectively showed close range permeability of $(2,20$, 15 and 5) mm capillary water absorption, and (133.3, 122, 130.4 and 170.1) $\mathrm{kg} / \mathrm{m}^{3}$ total water absorption, 
they matched that of the control specimen, $\mathrm{S} 1$ of $26 \mathrm{~mm}$ capillary water absorption, and $187.7 \mathrm{~kg} / \mathrm{m}^{3}$ total water absorption.

Specimen S11, which is within the same range of porosity of $46.4 \%$, had higher permeability of $70 \mathrm{~mm}$ capillary water absorption and $243 \mathrm{~kg} / \mathrm{m}^{3}$ total water absorption. Looking at the BS images of S11 and S12, when compared with S19 and S20, all brick-made had almost similar range of porosity of (46.4, $53.5,46.6$ and 57) \% respectively, but S19 and S20 of lower densities, showed improvement in respect of permeability. This is due to toner inclusion, which refined the pore system to a better pore size distribution of the smaller size micro pores of less than $10 \mu \mathrm{m}$, unlike S11 with uneven interconnected bigger size pores with a range of (50 to 70) $\mu \mathrm{m}$.

Taking S3 and S13 of the $1100 \mathrm{~kg} / \mathrm{m}^{3}$ density as control samples, with (60 and 66) \% porosity, $100 \mathrm{~mm}$ capillary water absorption, and $(288.7$ and 270$) \mathrm{kg} / \mathrm{m}^{3}$ total water absorption respectively, improvement for permeability was noted for capillary and total water absorption in S8, S15, S18 and S20. To note, specimen S20 (brick-made with toner inclusion), revealed 57\% porosity and displayed better performance in capillary water absorption of $35 \mathrm{~mm}$, while specimen S15 (brick-made with MK20 inclusion) had $51.6 \%$ porosity and performed better in total water absorption of $160.5 \mathrm{~kg} / \mathrm{m}^{3}$.

Porosity of all the mentioned samples were below $57.7 \%$, i.e. low porosity shows low permeability, apart from S8 with $70 \%$ with $31 \mathrm{~N} / \mathrm{mm}^{2}$ compressive strength, which is over the porosity of the control samples of sand and brick made of $1100 \mathrm{~kg} / \mathrm{m}^{3}$ density, S3 and S13 with $(7.4$ and 14.1$) \mathrm{N} / \mathrm{mm}^{2}$ respectively, this shows that porosity may not be the only factor controlling permeability, but strength is another factor which comes from the inclusion of MK or toner.

Looking at the $1600 \mathrm{~kg} / \mathrm{m}^{3}$ density, in comparison to $\mathrm{S} 12$ brick made only, porosity $53.5 \%$ with $86 \mathrm{~mm}$ capillary water absorption, and $249 \mathrm{~kg} / \mathrm{m}^{3}$ total water absorption, improvement is noted for S14 brick made with MK20 inclusion and S19 brick made with toner inclusion, having (130.4 and 170.1) kg/m total water absorption, and (15 and 5) mm capillary water absorption, respectively.

Meanwhile, S5 of sand made with MK20 inclusion is a better example for porosity improvement than S7, sand made with MK30 inclusion, having (54 and 65.1) \% porosity, with (34 and 81) mm capillary water absorption, and (170.7 and 205) kg/m ${ }^{3}$ total water absorption, respectively. Looking at $1800 \mathrm{~kg} / \mathrm{m}^{3}$ density, specimens S4 and S16 sand-made with MK20 and toner inclusion showed improvement in respect of porosity, having (39.8 and 39.6) \% respectively, compared to S11 of brick made only, having $46.4 \%$ porosity. This is followed by S5, S14, and S19 which are sand or brick made with the inclusion of either MK20 or toner.

Toner inclusion on sand or brick mixes of (1800 and 1600) kg/m $\mathrm{m}^{3}$ densities namely, S16 and S19 exhibited comparatively low porosity of (39.6 and 46.6) \%, with high compressive strength of (48.1 and 43.8) $\mathrm{N} / \mathrm{mm}^{2}$ respectively, having ( 2 and 5 ) $\mathrm{mm}$ capillary water absorption, signifying low permeability and almost water tight FC matrix. For the same purpose of permeability, MK20 inclusion appeared to be the second on the same (1800 and 1600) $\mathrm{kg} / \mathrm{m}^{3}$ densities, namely S4, S14, and S5 with $(39.8,44.5$ and 54) \% porosity, of (49.7, 46 and 47) N/mm ${ }^{2}$ compressive strength, which exerted (20, 15 and 34) mm capillary water absorption, respectively.

Based on the experimental results, all toner-contained specimens performed better in respect of permeability in comparison to the rest of the specimens. Toner and MK work in the same way for controlling permeability, as they refine the pores, the pore size, and their distribution, but with different mechanisms. Toner contains stearates that will interact with the fine air voids, producing a net of water repellent pores, and safeguarding their distribution to stay unconnected (from SEM images analysis). This minimizes or inhibits water movement through the FC matrix. Meanwhile, MK refines the air voids to a finer interconnecting but with a strong FC skeleton, altering the microstructure of the matrix, for which it may relatively be porous and allow a minimal, or inhibiting water movement through their body, while 
still maintaining the strength. Porosity for capillary water absorption has a different phenomenon from porosity for total water absorption.

Metakaolin makes a stronger FC matrix through the interconnecting air voids (micro pores) of the size up to $10 \mu \mathrm{m}$ and interlocking channels (set of interconnecting closely-packed micro pores) allowing poor water movement through these micro pores of the interlocking channels, while maintaining the strength with a firm skeleton. At the same time, this system of micro pores of the smaller size pores of $<10 \mu \mathrm{m}$ is produced within the firm skeleton, inhibiting water penetration through one direction for the improvement of the capillary water absorption under 5 bar water pressure.

Regardless of the density, specimens made without any additive, showed unevenly spaced relatively bigger irregularly-shaped pore diameters in the range of $(0.1$ to 70$) \mu \mathrm{m}$. The shape factor, which increases the porosity of the specimens, in turn, influences the control of permeability. This contradicts findings reported by Lange et al. [12] and Zhang et al. [13] stating that air void shape has no influence on the properties of FC, while those specimens made with MK20 or toner, showed an evenly-spaced and more regularly-shaped finer pore diameters in the range of (0.1 to 10.0) $\mu \mathrm{m}$ (see S4, S5, S14, S15, S16, S18 and S20). Specimens with $1800 \mathrm{~kg} / \mathrm{m}^{3}$ densities, or those with toner inclusion, showed even better compacted FC matrices with pore diameters in the range of (0.01 to 3.0) $\mu \mathrm{m}$.

MK30 and MK50 inclusion specimens, namely, S7, S8, and S10 exhibited relatively high porosity of (65.1, 70 and 77.7) \% respectively, which has an adverse effect in respect of permeability with (81, 74 and 100) mm capillary water absorption, while maintaining slight improvement on compressive strength, in comparison to $\mathrm{S} 3$ of sand only made mix, having $7.4 \mathrm{~N} / \mathrm{mm}^{2}$ compressive strength.

Depending on filler type and additives of the FC matrix, compressive strength between (50.5 and 30) $\mathrm{N} / \mathrm{mm}^{2}$ can result from the $1600 \mathrm{~kg} / \mathrm{m}^{3}$ densities, and at $1800 \mathrm{~kg} / \mathrm{m}^{3}$ densities, $(55.1$ and 31$) \mathrm{N} / \mathrm{mm}^{2}$, while at $1100 \mathrm{~kg} / \mathrm{m}^{3}$ densities, it can only meet the compressive strength requirement for structural use at 28.5 $\mathrm{N} / \mathrm{mm}^{2}$.

This means; light weight FC of the compressive strength of (55.1 to 28.5) N/mm² can optionally be chosen to match the minimal permeability or the strength requirement for structural use.

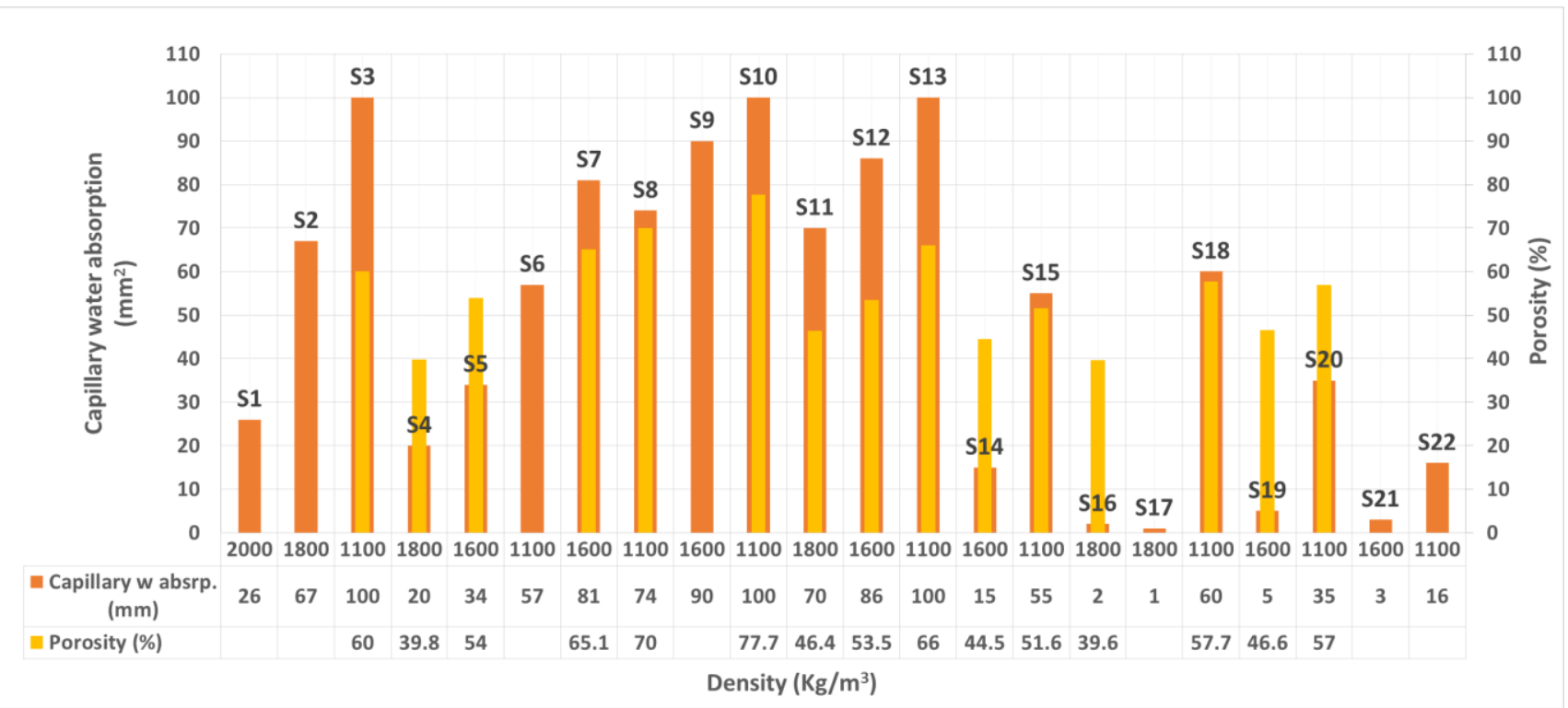

Figure 6 Porosity and capillary water absorption in relation to density for different mixes containing sand and brick as fillers, with the inclusion of toner and MK as additives for specimens with 28 days of sealed curing 


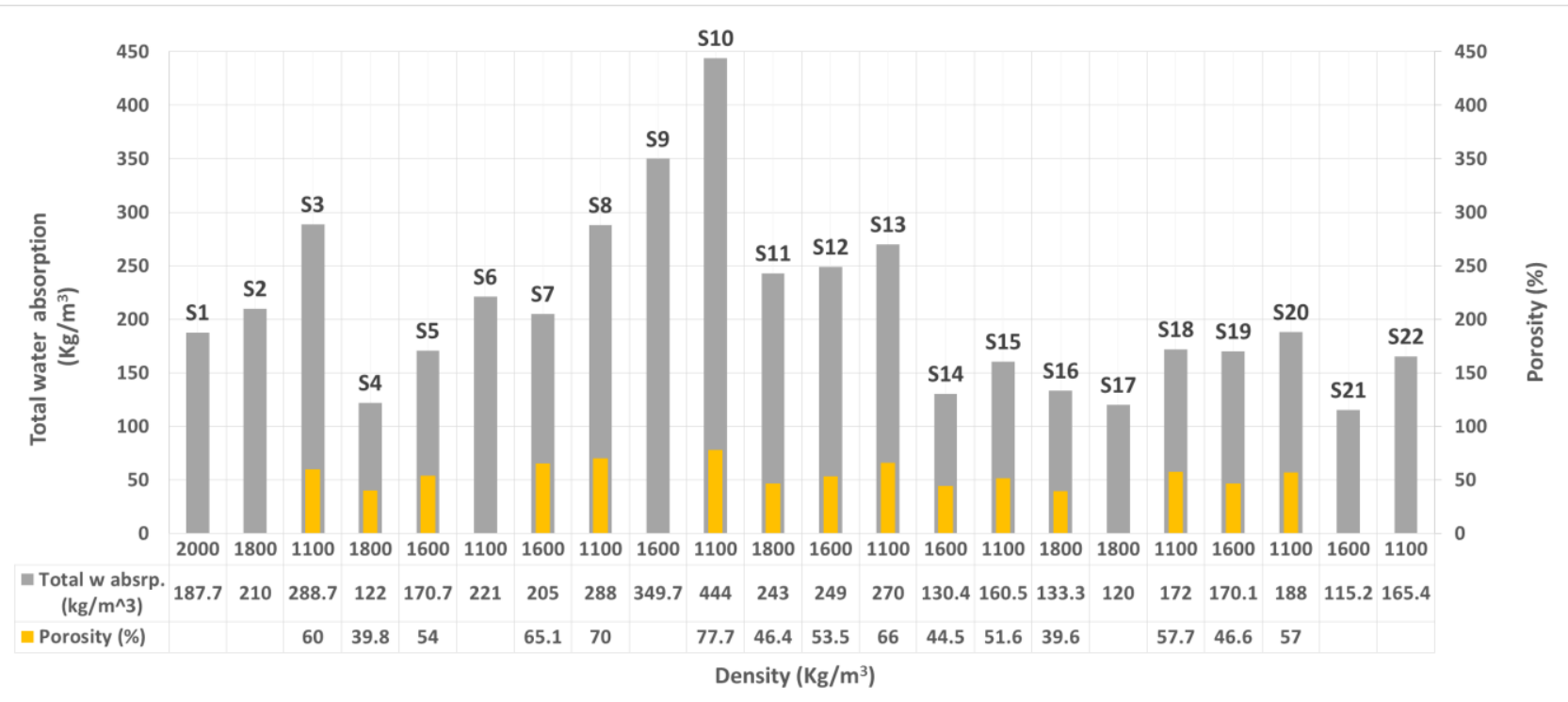

Figure 7 Porosity and total water absorption in relation to density for different mixes containing sand and brick as fillers, with the inclusion of toner and MK as additives for specimens with 28 days of sealed curing

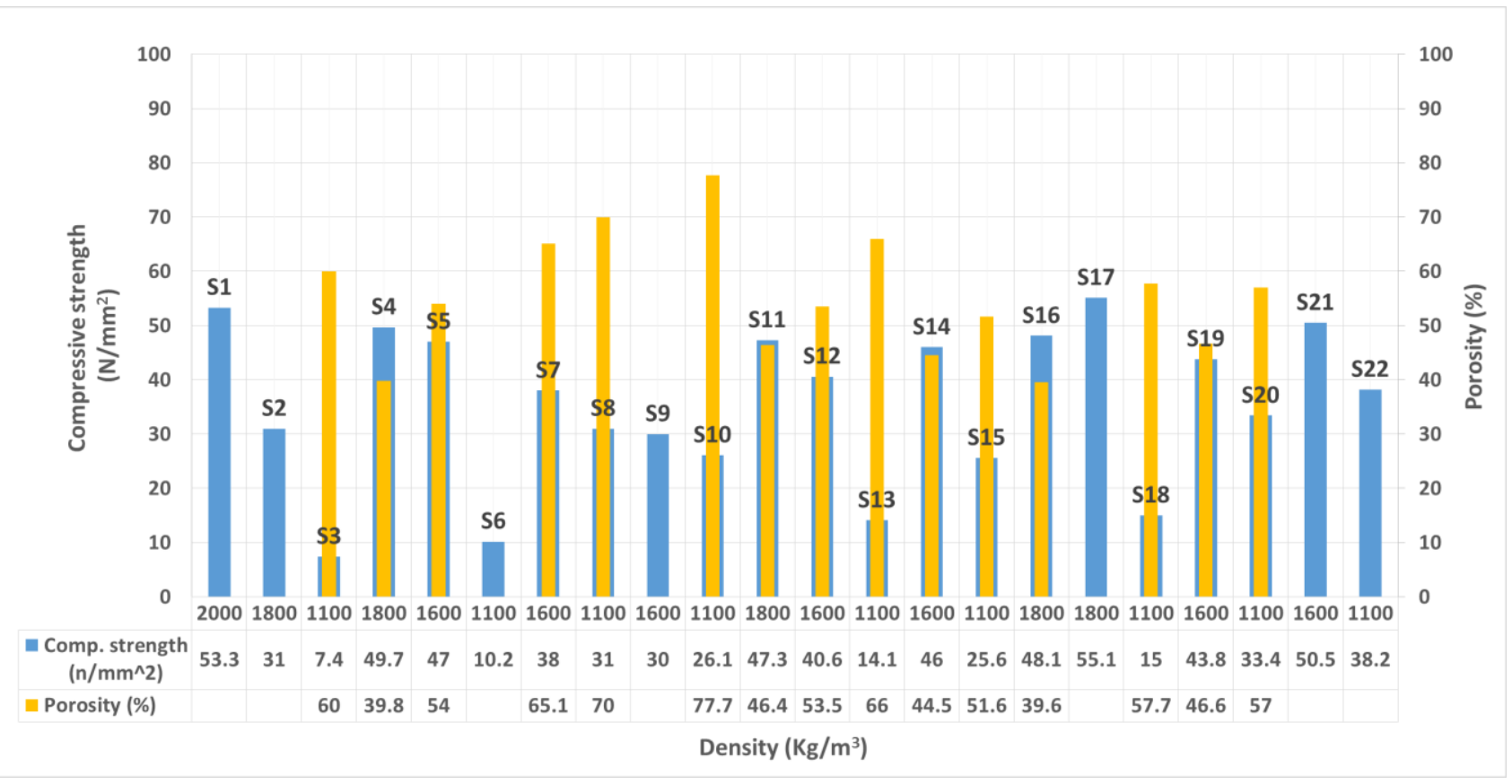

Figure 8 Porosity and compressive strength in relation to density for different mixes containing sand and brick as fillers, with the inclusion of toner and MK as additives for specimens with 28 days of sealed curing

\subsection{CONCLUSIONS}

The following conclusions can be drawn from the present study:

- The pore size of the FC of the densities $(1100,1600$ and 1800$) \mathrm{kg} / \mathrm{m}^{3}$ is in the range of (0.01 to 70) $\mu \mathrm{m}$ depending on the type of the additive. It is in the range of $(0.01$ to 3.0$) \mu \mathrm{m}$, for the mixes that contained toner, and ( 0.01 to 10.0$) \mu \mathrm{m}$ for mixes that contained MK.

- As for the FC specimen, the finer the pore size, the less porous, the less permeable and the stronger it is. Therefore, permeability is porosity dependent in a linear relation for FC mixes made with sand or brick only with no additive inclusion, which exhibits an unevenly distributed pore system of an irregular shape. While the FC mixes made with the inclusion of additives, such as the toner and MK20 inclusion mixes investigated, showed an evenly spread net of independent fine air voids (micro pores) 
with a regular shape within their matrix, which is beneficial in decreasing permeability. Therefore, porosity may stay high, i.e. an inverse relationship between porosity and permeability.

- Besides porosity and strength, the shape factor of the porous matrix is another key factor in controlling permeability.

- Toner and MK20 can refine porosity to decrease permeability of the FC for total and capillary water absorption. Toner and MK20 inclusion can enhance the capillary water absorption significantly to reach almost water tight at the (1800 and 1600) $\mathrm{kg} / \mathrm{m}^{3}$ densities. Even at the low densities of 1100 $\mathrm{kg} / \mathrm{m}^{3}$, toner can improve permeability to slightly exceed that of the control figures. While MK30 and MK50 inclusion have an adverse effect in respect of permeability.

- Depending on the filler type, the additive, and the percentage ratio of the porosity of the FC matrix, all the specimens having compressive strengths between $(55.1$ and 30) N/mm², of (1600 and 1800) $\mathrm{kg} / \mathrm{m}^{3}$ densities of this investigation can be chosen to meet the compressive strength requirement for the structural use at $28.5 \mathrm{~N} / \mathrm{mm}^{2}$. While at $1100 \mathrm{~kg} / \mathrm{m}^{3}$ densities, there are three specimens which can be chosen to meet this purpose. This means, light weight FC of the three densities namely, (1800, 1600 , and 1100) $\mathrm{kg} / \mathrm{m}^{3}$, and various compressive strength limits mentioned here, can be chosen to match the permeability or strength requirement for the structural use.

- FC with toner and MK20 inclusion at (1800 and 1600) kg/m ${ }^{3}$ densities can be selected for their highest compressive strength, and minimal permeability amongst the others, while at the $1100 \mathrm{~kg} / \mathrm{m}^{3} \mathrm{density}$, the FC with toner inclusion at $5 \%$ can be selected.

\section{REFERENCES}

[1] M. A. O. Mydin and Y. C. Wang, 2011. 'Structural performance of lightweight steel-foamed concrete-steel composite walling system under compression', Thin-Walled Structures, 49(1), 66-76.

[2] E. K. K. Nambiar and K. Ramamurthy, 2007b. Sorption characteristics of foam concrete, Cement and Concrete Research 37, 1341-1347.

[3] K. Ramamurthy, E. K. K. Nambiar and G. I. S. Ranjani, 2009. A classification of studies on properties of foam concrete. Cement and Concrete Composites 31, 388-396.

[4] N. Narayanan and K. Ramamurthy, 2000. Prediction relations based on gel-pore parameters for the compressive strength of aerated concrete. Concrete Science and Engineering 1 (2), 206-212.

[5] E. P. Kearsley and P. J. Wainwright, 2002. The effect of porosity on the strength of foamed concrete, Cement and Concrete Research 32, 233-239.

[6] R. Kumara and B. Bhattacharjeeb, 2003. Porosity, pore size distribution and in situ strength of concrete. Cement and Concrete Research 33, 155-164.

[7] E. K. K. Nambiar and K. Ramamurthy, 2007. Air-void characterisation of foam concrete, Cement and Concrete Research 37, 221-230.

[8] Y. Xingang, L. Y. G. Shisong, W. Y. L. Hongfei, W. Yurong and W. Xiaojian, 2011. Pore Structure and Microstructure of Foam Concrete, Advanced Materials Research 177, 530-532

[9] M. Visagie and E. P. Kearsely, 2002. Properties of foamed concrete as influenced by air-void parameters. Concrete Beton 101, 9-13.

[10] T. Luping, 1986. A study of the quantitative relationship between strength and pore-size distribution of porous materials. Cement and Concrete Research 16, 87-96.

[11] A. A. Hilal, N. H. Thom and A. R. Dawson, 2014. Pore Structure and Permeation Characteristics of Foamed Concrete, Journal of Advanced Concrete Technology 12, pp 535-544.

[12] D. A. Lange, H. M. Jennings and S. P. Shah, 1994. Image analysis techniques for characterisation of pore structure of Cement-based materials. Cement and Concrete Research 24 (5), 841-853.

[13] Z. Zhang, F. Ansari and N. Vitillo, 2005. Automated determination of entrained air void parameters in hardened concrete, ACI Materials Journal 102 (1), 42-48.

[14] M. R. Jones and A. McCarthy, 2006. Heat of hydration in foamed concrete: Effect of mix constituents and Plastic density. Cement and Concrete Research 36 (6), 1032-1041.

[15] J. Ambroise, M. Murat and J. Pera, 1985. Hydration reaction and hardening of calcined clays and related minerals. Cement and Concrete Research 15: 261-268.

[16] J. M. Khatib and S. Wild, 1996. Pore size distribution of metakaolin paste. Cement and Concrete Research 26 (10), $1545-1553$.

[17] J. Ding and Z. Li, 2002. Effects of metakaolin and silica fume on properties of concrete. ACI Mater J 99 (4): $393-$ 398.

[18] A. L. Cherem, J. P. Gon, P. M. Büchler and J. Dweck, 2008. Effect of metakaolin pozzolanic activity in the early stages of cement type ii paste and mortar hydration. Journal of Thermal Analysis and Calorimetry, Vol. 92, 1, 115119 . 
[19] P. Chindaprasirt, S. Homwuttiwong and V. Sirivivatnanon, 2004. Influence of fly ash fineness on strength, dryingshrinkage and sulfate resistance of blended cement mortar. Cement and Concrete Research 34: 1087-1092.

[20] K. A. Gruber, R. T. amlochan, R. D. Hooton and M. D. A. Thomas, 2001. Increasing concrete durability with highreactivity metakaolin. Cement and Concrete Composites, Vol. 23, 6, 479-484.

[21] A. Balogh, 1995. High-reactivity metakaolin. Concrete Construction 40 (7), 604-610.

[22] J. A. Kostuch, G. V. Walters and T. R. Jones, 1993. In: Dhir RK, Jones MR, editors. High performance concrete incorporating metakaolin: a review. Concrete 2000. E \& FN Spon; 1799-811.

[23] F. Bektas and K. Wang, 2012. Performance of ground clay brick in ASR-affected concrete: Effects on expansion, mechanical properties and ASR gel chemistry. Cement and Concrete Composites 34, 273-278.

[24] G. Moriconi, V. Corinaldesi and R. Antonucci, 2003. Environmentally friendly mortars: a way to improve bond between mortar and brick. Materials and Structures 36, 702-708.

[25] L. Turanli, F. Bektas and P. Monterio, 2003. Use of ground clay brick as a pozzolanic material to reduce the alkali silica reaction. Cement and Concrete Research 33, 1539-1542.

[26] A. A. Aliabdo, A. M. Abd-Elmoaty, and H. H. Hassan, 2014. Utilization of crushed clay brick in cellular concrete production. Alexandria Engineering Journal, 53, 119-130.

[27] F. Debieb and S. b. Kenai, 2008. The use of coarse and fine crushed bricks as aggregate in concrete. Construction and Building Materials 22, 886-893.

[28] N. M. Ibrahim, S. Salehuddin, R. C. Amat, N. L. Rahim and T. N. T. Izhar, 2013. Performance of Lightweight Foamed Concrete with Waste Clay Brick as Coarse Aggregate. APCBEE, Procedia 5, 497 - 501.

[29] P.B. Cachim, 2009. Mechanical properties of brick aggregate concrete. Construction and Building Materials 23, 1292- 1297.

[30] V.P. Sandra, 2014. Harvard Physico-chemical and toxicological studies of engineered nanoparticles emitted from printing equipment. Harvard school of public health.

[31] N. B. Winter, 2012. Scanning Electron Microscopy of the Cement and Concrete.

[32] BS EN 12390-8:2009, Testing for capillary water absorption.

[33] BS 1881-122:2011, Testing for total water absorption.

[34] BS EN 12390-3:2009, Testing hardened concrete. 